PRZEGLĄD NAUK HISTORYCZNYCH 2018, R. XVII, NR 1

http://dx.doi.org/10.18778/1644-857X.17.01.07

Matgorzata Karkocha

UNIWERSYTET ŁÓDZKI*

\title{
Opis probostwa w Małogoszczu z 1856 roku
}

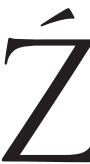

ródła do dziejów kościoła i probostwa w Małogoszczu były już przedmiotem edycji na łamach „Przeglądu Nauk Historycznych". Ukazały się teksty omawiajace uposażenie parafii małogoskiej w 1792 r. ${ }^{1}$, protokół wizyty dziekańskiej z 1830 r. $^{2}$, jak również opis świątyni parafialnej zaczerpnięty $z$ inwentarza fundi instructi z $1856 r .{ }^{3} \mathrm{Z}$ tego samego źródła pochodzi opis uposażenia, dochodów oraz stanu budynków należących do probostwa w Małogoszczu, stanowiący podstawę niniejszego wydania.

Wspomniany inwentarz został sporządzony po śmierci miejscowego plebana, ks. Tomasza Świątkowskiego ${ }^{4}$. Przechowywany jest w Archiwum Diecezjalnym w Kielcach, w księdze zatytułowanej

* Wydział Filologiczno-Historyczny, Instytut Historii, Katedra Historii Nowożytnej, e-mail: malkarkocha@o2.pl.

${ }^{1}$ Por. M. Karkocha, Uposażenie parafii Małogoszcz $w$ świetle sumariusza z 1792 r., „Przegląd Nauk Historycznych” 2016, R. XV, nr 1, s. 249-276.

${ }^{2}$ Eadem, Opis wizyty dziekańskiej kościoła parafialnego w Małogoszczu z roku 1830, „Przegląd Nauk Historycznych” 2016, R. XV, nr 2, s. 261-283.

${ }^{3}$ Ead e m, Wystrój i wyposażenie kościoła parafialnego $w$ Małogoszczu $w$ świetle inwentarza z 1856 roku, „Przegląd Nauk Historycznych” 2017, R. XVI, nr 1, s. 325-362.

4 Tomasz Świątkowski (1786-1855) - doktor teologii, kanonik i oficjał kielecki, proboszcz małogoski w latach 1836-1855. Por. Archiwum Diecezjalne w Kielcach [dalej: ADK], Akta konsystorskie ogólne. Życiorysy kapłanów 1835, sygn. OP-X/4b, k. 206-206v; ibidem, Akta konsystorskie. Status cleri 1847-1929, sygn. OP-X/13, k. 1012-1013; oraz J. Wiśniewski, Historyczny opis kościołów, miast, zabytków i pamiątek $w$ Jędrzejowskiem, Marjówka 1930, reprint: Kielce 2000, s. 138, 272-273 (na s. 138 błędna informacja, jakoby Świątkowski zmarł w 1856 r., a na s. 272, że urodził się 1785 r.). 
Małogoszcz. Dokumenty różne z XIX wieku (luzem, nieuporząkowane), opatrzonej sygnatura IIPM-I/6. Spisano go w języku polskim na kartkach formatu zbliżonego do A4, zapisanych obustronnie, ponumerowanych od 1 do 77 , oznaczonych współcześnie jako k. 41-79. Pismo jest czytelne, a w tekście dokonano nielicznych poprawek. Brakuje kilku kart, które zostały wyrwane. Spisu sporządziła specjalna komisja złożona $z$ osób duchownych (dziekana kieleckiego ks. Stanisława Zygmuntowicza ${ }^{5}$ i nowo obranego proboszcza, ks. Nestora Bierońskiego ${ }^{6}$ ) oraz świeckich (burmistrza miasta Małogoszcz Karola Syktowskiego, prezesa dozoru kościelnego Jana Mieszkowskiego ${ }^{7}$ oraz dwóch jego członków: Jana Saskiego $^{8}$ i Józefa Wodzyńskiego ${ }^{9}$ ). Poświadczył go i uwierzytelnił pieczęcią w dniu 11 (23) lipca 1856 r. zastępca naczelnika powiatu kieleckiego.

5 Stanisław Zygmuntowicz (1806-1866) - kapłan diecezji kieleckiej, wyświęcony w 1830 r. Początkowo pełnił funkcję wikariusza w Kurzelowie. W latach 1833-1866 był administratorem, a następnie proboszczem kościoła parafialnego w Złotnikach. W 1841 r. został zastępca dziekana (poddziekanem), a w roku 1846 dziekanem diecezji kieleckiej. Por. ADK, Akta konsystorskie. Status cleri 1847-1929, sygn. OP-X/13, k. 1284-1285; ibidem, Akta konsystorskie ogólne. Życiorysy kapłanów 1835-1840, sygn. OP-X/3, k. 30.

${ }^{6}$ Nestor Hygin Soter Bieroński (1816-1899) - kapłan diecezji kieleckiej i wieloletni wykładowca Seminarium Duchownego w Kielcach, proboszcz małogoski w latach 1855-1899. Biogram tego kapłana w: M. Karkocha, Parafia Rembieszyce 1438-2012. Studium z dziejów społeczności lokalnej, Łódź 2013, s. 357-359. Por. ADK, Akta personalne ks. Nestora Bierońskiego 1842-1890, sygn. XB-19; ibidem, Akta konsystorskie. Status cleri 1847-1929, sygn. OP-X/13, k. 50-51; W. Gi eb ar tow ski, Ś.p. ks. Nestor Bieroński, „Przegląd Katolicki” 1899, R. XXXVII, nr 18, s. 281-284; ks. S. S tu czeń, Parafia małogoska i jej ostatni proboszcz ś.p. ks. praŁat ks. Nestor Bieroński, „Przegląd Katolicki” 1899, R. XXXVII, nr 21, s. 328-330 oraz nr 22, s. 345-346; J. Wi śn niew ski, op. cit., s. 273.

7 Jan Mieszkowski - właściciel wsi Cieśle, dzierżawca Leśnicy i Skorkowa. Por. Protokół wyboru Dozoru Kościelnego w Małogoszczu z 1859 r., ADK, Małogoszcz. Dokumenty różne z XIX wieku (luzem, nieuporządkowane), sygn. IIPM-I/6, k. 105.

8 Jan Saski (1810-1868) - kolator miejscowego kościoła, od 1854 r. dzierżawca rozległych dóbr rządowych w powiecie kieleckim, złożonych z 13 wsi i osad (Ruda, Wesoła, Młynki, Zajączków, Krawczowskie, Laski, Miedzianka, Podpolichno, Charężów, Gałęzice, Fanisławice, Fanisławiczki i Gnieździska), a wcześniej (w latach 1847-1852) właściciel pobliskiej wsi Mieronice. Jego mogiła znajduje się na cmentarzu parafialnym w Małogoszczu. Por. K. Zapałowa, Rodzina Stefana Żeromskiego w Świętokrzyskiem, Kielce 2003, s. 172 i n.; M. Karkocha, Parafia Rembieszyce..., s. 72, 75; oraz Protokół wyboru Dozoru Kościelnego..., k. $105-105 \mathrm{v}$.

9 Józef Wodzyński - posiadacz realności w Małogoszczu. Por. Protokół wyboru Dozoru Kościelnego..., k. 105-105v. 


\section{Komentarz}

Pierwsza wzmianka na temat kościoła parafialnego w Małogoszczu pochodzi z $1141 \mathrm{r}$. Nie zachował się żaden dokument jego fundacji i erekcji. Kościół wraz z grodem zniszczyli Tatarzy w 1259 r. Po przeniesieniu miasta na nowe miejsce wzniesiona została drewniana świątynia pw. św. Mikołaja bpa i św. Małgorzaty, dziewicy i męczennicy. W 1342 r. hojnie uposażył ją król Kazimierz Wielki, przekazując miejscowemu plebanowi Janowi, archidiakonowi sandomierskiemu i kanonikowi krakowskiemu, zachodnią część miasta oraz rozległy kompleks gruntów od cmentarza do rzeki Pierzchnicy. Darował mu też wieś Popowice nad Nidą $z$ wszystkimi przynależnościami. Nadanie uzupełnione zostało cłem królewskim z miast Małogoszcza, Kurzelowa i Chęcin, ściąganym co dziewiąty dzień, a także dwoma świątnikami spośród miejscowych mieszczan (Piotrem Petro i Mikołajem Słowikiem), których zadaniem była obsługa kościoła. Od tego czasu beneficjum małogoskie zaliczane było do bardziej dochodowych. Przeważnie zreszta otrzymywali je wysocy dygnitarze duchowni lub osoby mile widziane na dworze królewskim, jako że było kolacji monarszej ${ }^{10}$.

Drewniany kościół przetrwał do końca XVI stulecia. Nie wiadomo, co się $z$ nim stało. Prawdopodobnie uległ zniszczeniu wskutek starości i został rozebrany. Obecna świątynia pw. Wniebowzięcia Najświętszej Marii Panny powstała w latach 1591-1595 z inicjatywy ks. Jakuba Biedy Chrostkowica (vel Chrostkowicza, Chrostka) (1560-1630), miejscowego mansjonarza, późniejszego proboszcza i dziekana małogoskiego ${ }^{11}$. Konsekrował ja w 1595 r. biskup chełmiński i wieczysty administrator diecezji pomezańskiej Piotr Tylicki $(1543-1616)^{12}$. Jest to budowla orientowana, murowana $z$ kamie-

${ }^{10}$ J. Wiśniewski, op. cit., s. 116-117; E. Kosik, Parafia małogoska, [w:] W kasztelańskim Małogoszczu. Monografia historyczno-gospodarcza Małogoszcza i okolicy, red. E. Kosik, Kielce 1994, s. 60-61; C. Had a mik, D. Kalin a, E. Traczyńs ki, Miasto i gmina Małogoszcz [seria: Dzieje i zabytki małych ojczyzn, red. R. Mirowski], Kielce 2006, s. 118-119; M. Rawita-Wit a nows ki, Dawny powiat chęciński, oprac. D. Kalina, Kielce 2001, s. 104, 108.

${ }_{11}$ Więcej na jego temat por. J. Wiśniewski, op. cit., s. 214-231; M. Rawita-Witanowski, op. cit., s. 109-119; E. Kosik, Chrostowice z Małogoszcza, „Nasza Przeszłość” 1973, R. XL, s. 176-181; idem, M. Paulewicz, Budowniczy Małogoszcza Jakub Bieda Chrostkowicz, [w:] W kasztelańskim Małogoszczu..., s. 67-70; ks. S. S tu czeń, Parafia małogoska i jej ostatni proboszcz ś.p. ks. prałat ks. Nestor Bieroński, „Przegląd Katolicki” 1899, R. XXXVII, nr 19, s. 296.

12 Piotr Tylicki herbu Lubicz - biskup chełmiński w latach 1595-1600 (z tej racji był także wieczystym administratorem diecezji pomezańskiej), a wcześniej 
nia wapiennego i cegły, otynkowana, oszkarpowana na narożach. Ma jedną nawę na planie wydłużonego prostokąta oraz węższe i niższe od niej prezbiterium, zamknięte trójbocznie. Przy prezbiterium od strony północnej znajduje się zakrystia i niewielki skarbczyk, a przy nawie kaplica pw. Matki Boskiej Różańcowej oraz pięcioboczna przybudówka $z$ kruchtą w przyziemiu i składzikiem na piętrze. Druga kaplica, dedykowana św. Annie, usytuowana jest od południa. Do kościoła przylega od zachodu masywna czworoboczna wieża, ukończona w 1624 r. Przed nią znajduje się niezbyt obszerna kruchta, przybudowana w 1894 r. ${ }^{13}$

W połowie XIX stulecia świątynia miała bogate wyposażenie. Składały się na nie: ołtarz główny ze słynąca cudami figurą Chrystusa Ukrzyżowanego, pięć ołtarzy bocznych (św. Jakuba Apostoła, św. Mikołaja, św. Anny, Matki Boskiej oraz nieistniejący dziś ołtarz św. Antoniego), dwa chóry, marmurowa chrzcielnica, ambona, stalle, ławki, konfesjonały oraz liczne obrazy. Była też dobrze zaopatrzona w naczynia i paramenty liturgiczne ${ }^{14}$.

Warto nadmienić, że ks. Jakub Bieda Chrostkowic był prawdziwym dobrodziejem miejscowej parafii. Oprócz świątyni parafialnej wzniósł na terenie Małogoszcza dwa inne murowane kościoły: filialny (obecnie cmentarny) pw. św. Stanisława (konsekrowany w 1599 r.) oraz szpitalny pw. Krzyża Świętego (wystawiony w 1609 r., konsekrowany w 1617 r.). Ufundował ponadto prebendę św. Anny (1600), szpital dla ubogich zwany Betanią, wybudował dom dla proboszcza szpitalnego (w latach 1609-1615), ustanowił wreszcie w Akademii Krakowskiej trzyletnie stypendium dla studentów z Małogoszcza w wysokości 1000 zł (1627) ${ }^{15}$.

(od 1578) proboszcz małogoski. Na jego temat por. L. Łętowski, Katalog biskupów, prałatów i kanoników krakowskich, t. II (Biskupi krakowscy), Kraków 1852, s. 162-169; B. Kumor, Dzieje diecezji krakowskiej do roku 1795, t. I, Kraków 1998, s. 520-521; S. Achremczyk, R. Marchwiński, J. Przeracki, Poczet biskupów warmińskich, Olsztyn 1994, s. 125-127; P. Nitecki, Biskupi Kościoła $w$ Polsce $w$ latach 965-1999, Warszawa 2000, s. 458. O działalności P. Tylickiego na probostwie w Małogoszczu por. J. Wiśniewski, op. cit., s. 205-209.

13 J. Wiśniewski, op. cit., s. 118-119; E. Kosik, Parafia małogoska..., s. 63; C. Hadamik, D. Kalina, E. Traczyński, op. cit., s. 176-177; Katalog zabytków sztuki w Polsce, t. III (Województwo kieleckie), red. J.Z. Łoziński, B. Wolff, z. 3 (Powiat jędrzejowski), oprac. T. Przypkowski, Warszawa 1957, s. 18.

${ }_{14}$ Szczegółowo na ten temat por. M. Karkocha, Wystrój i wyposażenie..., s. 328 oraz tekst źródłowy, s. 333-358.

15 Por. J. Wiśniewski, op. cit., s. 134 i n.; E. Kosik, Parafia małogoska..., s. 63; idem, Chrostowice..., s. 177-179; M. Paulewicz, op. cit., s. 69. 
Parafia małogoska obejmowała początkowo dość rozległy obszar. W jej skład wchodziło miasto Małogoszcz oraz siedem okolicznych wsi: Leśnica, Skorków, Cieśle, Bolmin, Gnieździska, Zajączków i Ruda Zajączkowską. Ze sporządzonego przez Jana Łaskiego wykazu beneficjów diecezji gnieźnieńskiej (Liber beneficiorum) wynika, że na początku XVI w. do parafii małogoskiej należał także dwór $\mathrm{w}$ Lasochowie, $\mathrm{z}$ którego pierwotnie oddawano dziesięcinę do stołu arcybiskupa gnieźnieńskiego, a następnie (od 1167 r.) do klasztoru cystersów w Jędrzejowie ${ }^{16}$. W 1574 r. w Bolminie powstała odrębna parafia ${ }^{17}$. Pozostałe miejscowości przynależały do małogoskiego okręgu parafialnego jeszcze w XIX w. ${ }^{18}$

Od początku swojego istnienia parafia małogoska wchodziła w skład archidiecezji gnieźnieńskiej. Zapewne na początku XIV w. znalazła się w granicach nowo erygowanego archidiakonatu kurzelowskiego, który był najbardziej wysuniętym na południowy wschód okręgiem administracyjnym tej archidiecezji ${ }^{19}$. Około 1604 r. Małogoszcz stał się siedzibą dekanatu, obejmującego wówczas 15 parafii (Małogoszcz, Chęciny, Bolmin, Chełmce, Mniów, Grzymałków, Strawczyn, Łopuszno, Mnin, Krasocin, Kozłów, Węgleszyn, Cierno, Złotniki i Rembieszyce). Do połowy XVIII stulecia dziekanami byli na ogół proboszczowie małogoscy, w późniejszym zaś czasie funkcję tę sprawowali przeważnie kanonicy kurzelowscy. Przemiany polityczne zachodzace na ziemiach polskich na przełomie XVIII i XIX w. pociągnęły za sobą konieczność reorganizacji administracji kościelnej. W 1805 r. papież Pius VII (1742-1823) bulla Indefessum personarum regnia dignitate fulgentium zniósł diecezję tarnowska, a w jej miejsce utworzył kielecką ze stolicą biskupią w Kielcach. W toku tych zmian zlikwidowany został dekanat małogoski, którego wschodnie parafie (Bolmin, Kozłów, Rembieszyce, Węgleszyn i Złotniki) wraz $z$ małogoską weszły w skład dekanatu chęcińskiego, północne (Chełmce, Grzymałków, Krasocin, Łopuszno, Mnin, Mniów, Piekoszów i Strawczyn) do kieleckiego, południowe zaś (Cierno) do jędrzejowskiego. Po likwidacji dekanatu

16 C. Hadamik, D. Kalina, E. Traczyński, op. cit., s. 108, 119; E. Kosik, Parafia małogoska..., s. 59; S. Borkiewicz, Z. Lin ow ski, Monografia historyczna i gospodarcza ziemi jędrzejowskiej, Kielce 1937, s. 73.

17 http://www.diecezja.kielce.pl/parafie/bolmin-narodzenia-nmp.

18 Por. m.in. M. Karkocha, Opis wizyty dziekańskiej..., s. 267; oraz edytowany inwentarz z $1856 \mathrm{r}$.

${ }_{19}$ W kwestii archidiakonatu w Kurzelowie por. ks. D. Wojciechow ski, Parafia w Kurzelowie, Kielce 1997, s. 25 i n. 
chęcińskiego w 1819 r. Małogoszcz został włączony do dekanatu kieleckiego. Stan taki utrzymywał się do roku 1911, gdy ks. bp Augustyn Łosiński (1867-1937) utworzył wicedekanat małogoski, przekształcony następnie - po odzyskaniu niepodległości przez państwo polskie - w dekanat ${ }^{20}$.

Przygotowany do edycji inwentarz otwieraja informacje ogólne, dotyczące m.in. daty konsekracji kościoła, położenia parafii, prawa prezenty. Następnie wyszczególnione zostały grunty należące do probostwa w Małogoszczu, jak również w osadzie Popowice. Opis zawiera dane na temat areału posiadanych dóbr oraz ich rodzajów pod względem zagospodarowania (grunty orne, łąki, pastwiska, ogród owocowy, nieużytki, lasy, zarośla, rzeki i stawy, obszary zabudowane). Określając lokalizację gruntu, podano lokalne nazwy topograficzne, np. młyn pod Jaworem, staw Jawór, las Sabianów, łaka pod Babinkiem, chałupa na Ściegnach. Usytuowanie określano również względem takich obiektów, jak młyn wodny, sad i dziedziniec proboszczowski, cmentarz. Punktem odniesienia były też cieki wodne (rzeki Nida i Łososina, rzeka biorąca swój początek od Kozłowa).

W dalszej części dokumentu zamieszczono informacje na temat uposażenia i wysokości dochodów beneficjum małogoskiego. Wymieniono wsie należace do parafii i podano ich zaludnienie. Opisano wygląd i stan nieruchomości będących składnikiem majątku kościelnego, czyli dom mieszkalny proboszcza, mansjonarię, budynki folwarczne, młyn, chałupy położone w różnych częściach Małogoszcza i pod lasem plebańskim. Wyszczególniono liczbę zagrodników, komorników i kmieci zamieszkujących osadę Popowice i odrabiających pańszczyznę dla probostwa $z$ podaniem wymiaru ich obciążen. Zamieszczono wreszcie spis zasiewów gruntowych, inwentarza żywego oraz sprzętów gospodarskich stanowiących własność parafii. Ostatnim elementem edytowanej części rękopisu jest wykaz czystego dochodu (intraty) beneficjum w Małogoszczu według spisu z $1818 \mathrm{r}$.

Omawiane źródło dostarcza szereg informacji na temat sytuacji ekonomicznej probostwa w połowie XIX w. Odwołuje się przy tym

${ }^{20}$ Szczegółowo na temat reorganizacji diecezji kieleckiej w omawianym okresie por. m.in. B. Kumor, Organizacja terytorialna diecezji kieleckiej, „Nasza Przeszłość” 1963, t. XVII, s. 192-215; T. Wróbe1, Zarys historii diecezji kieleckiej, „Kielecki Przegląd Diecezjalny” 1982, R. LVIII, nr 5, s. 206-208. O przynależności Małogoszcza do administracji kościelnej por. J. W iśn nie w s ki, op. cit., s. 162-164; E. Kosik, Parafia małogoska..., s. 59, 63-65. 
do danych ze spisu z 1818 r., jak dotąd nieodnalezionego. Przynosi też szczegółowe wiadomości dotyczące wsi funduszowej Popowice. Cenne sa wzmianki odnoszace się do szkoły elementarnej w Małogoszczu oraz liczby ludności poszczególnych osad wchodzacych w skład małogoskiego okręgu parafialnego. Informacje o stanie budynków kościelnych oraz uposażeniu probostwa można porównać $z$ opisem $z 1830 \mathrm{r}$.

\section{Metoda wydawnicza}

Edycja dokumentu została opracowana zgodnie $z$ wymogami instrukcji wydawniczej Kazimierza Lepszego ${ }^{21}$. Zmodernizowano zatem pisownię źródła, zachowując jednak jego cechy językowe. Poprawiono także interpunkcję, głównie przez dodanie przecinków i kropek kończących zdanie w miejsce myślników stosowanych w podstawie wydania. Dwukropek, jako znak kończący skrót, zamieniono na kropkę. Samogłoski „i”, „y” oraz spółgłoskę „j” oddano zgodnie $z$ aktualnie obowiąujacymi zasadami. W przypadku, gdy litera "y" oznaczała dwie głoski, zapisano to zgodnie $z$ wymowa, np. „diecezya” jako „diecezyja”, „propinacya” jako „propinacyja”. Znak „ó” zastosowano według obecnych reguł pisowni. Podwojone głoski „ss” i „mm” zastapiono pojedynczymi, np. w słowach „lassy”, „summy”, „kommissya”. Uwspółcześniono pisownię wyrazów zakończonych w rękopisie na -em i -emi, np. „rządowem”, „temi” zmieniono na „rządowym”, „tymi”. Uzupełniono również pomijane niekiedy znaki diakrytyczne, takie jak „ę", „ó,, „śs”, „ć". Usunięto litere „x", zastępując ja dwuznakiem „ks” (np. w nazwie miejscowej „Oxa”). Słowo „wrzeciąz” oddano zgodnie $z$ regułami dzisiejszej pisowni jako „wrzeciądz”. Także zgodnie $z$ obecną praktyką użyto wielkich liter. Wyrazy, które odbiegają od współczesnej pisowni, a nie zostały poprawione przez wydawcę, opatrzono skróconym sic $\mathrm{w}$ nawiasie kwadratowym [s] dla upewnienia czytelnika o zgodności tekstu wydanego $z$ podstawa. $W$ takich samych nawiasach ujęto początek danej strony w oryginale, rozwiązano skróty, zaznaczono miejsca nieczytelne, uzupełniono nadto opuszczone przez pisarza litery. W przypisach tekstowych zamieszczono uwagi odnoszące się do postaci zewnętrznej i brzmienia tekstu źródłowego, jak również lekcje wattpliwe. W przypisach rzeczowych objaśniono

${ }^{21}$ Instrukcja wydawnicza dla źródeł historycznych od XVI do połowy XIX wie$k u$, red. K. Lepszy, Wrocław 1953. 
znaczenie niektórych terminów. Zachowano podkreślenia wyrazów oraz układ tekstu znajdujący się w rękopisie. W edycji występują skróty: N., № - numer, numero; J.W. - Jaśnie Wielmożny; Wo - Wielmożnego.

$\mathrm{Na}$ koniec dwie istotne informacje. W dokumencie występują liczne podkreślenia ołówkiem i dopiski, wynikające $z$ późniejszej ingerencji w tekst. W celu zredukowania liczby przypisów zrezygnowano $z$ informowania o tym $\mathrm{w}$ osobnych odsyłaczach. $Z$ kolei opis budynków mieszkalno-gospodarczych probostwa został w podstawie wydania sporządzony $\mathrm{w}$ pięciokolumnowej tabeli, zawierajacej liczbę porządkową, wyszczególnienie budowli, wartość według oszacowania (w rublach srebrnych) oraz uwagi. Ze względów technicznych zrezygnowano $z$ graficznego odwzorowania tych kolumn, umieszczając informacje o wartości na końcu opisu, a ewentualne uwagi w przypisach. W rubryce „Uwagi” znajduja się także notatki dotyczace stanu zachowania zabudowań, poczynione ołówkiem i innym charakterem pisma, czyli wtórne wobec źródła, które także pominięto w edycji.

$$
* * *
$$

Inwentarz fundi instructi kościoła parafialnego beneficjum w mieście Małogoszczu po śmierci X. Tomasza Świątkowskiego proboszcza na osobę W.X. Nestora Bierońskiego wiceregensa seminarium kieleckiego, nowo ustanowionego proboszcza w Małogoszczu w roku 1856 sporządzony

Or.: Archiwum Diecezjalne w Kielcach, Małogoszcz. Dokumenty różne z XIX wieku (luzem, nieuporzadkowane), sygn. IIPM-I/6, k. 41-79.

\section{Opisanie historyczne kościoła i jego funduszów}

[k. 47] Kościół parafialny w mieście Małogoszczu pod tytułem N[ajświętszej] M.[arii] Panny Wniebowzięcia w powiecie i obwo-

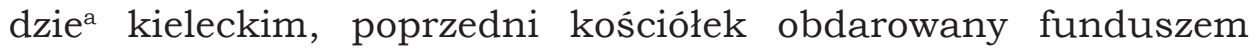
w r.[oku] 1342 od Najjaśniejszego Kazimierza Wielkiego, króla polskiego, a powtórnie wystawiony przez księdza Jakuba Chrostkiewicza $^{22}$, proboszcza małogoskiego w r.[oku] 1595 i konsekrowany

\footnotetext{
a Nadpisane nad wierszem ołówkiem: „okręgu”.

22 Jakub Bieda Chrostkowic, por. przyp. 11.
} 
w tymże roku od śp. JW. Księdza Piotra Tylickiego, biskupa chełmskiego $^{23}$. Kościół ten jako w mieście rządowym Małogoszczu zostaje pod opieką rządu, należy do dekanatu kieleckiego diecezyi krakowskiej.

\section{Odległość od miasta}

Od miasta Kielce mil cztery, od miasta Krakowa odległy mil czternaście, ma także naokoło pomniejsze miasteczka, jako to Jędrzejów mil trzy, Włoszczowa mil trzy, Chęciny mil dwie.

\section{Prawo prezenty}

Od początku nadania funduszów i dotąd należy jedynie do rządu.

\section{Własność ziemi}

Grunta po większej części górzyste, mało rędziny, a więcej piaskowego, lecz użyteczny.

\section{Łaka przy probostwie}

Jest tylko jedna, lecz pagórkowata, nie zawsze użyteczna.

Mineralia - w gruntach do probostwa należących nie ma żadnych widocznych mineraliów.

\section{$\underline{\text { Rzeki znaczniejsze }}$}

Rzeki w ogólności żadne $z$ gruntami, łąkami, lasami do probostwa w Małogoszczu należącymi nie graniczą, jednak w odległości [k. 47v] mili jednej przedziela granice miasta Małogoszcza rzeka Nida i druga mała rzeka Łososina, o jedne czwarta mili od miasta odległa, przechodzi przez granice miejskie.

\section{Propinacyje}

Do dochodu probostwa należą duże propinacyje, to jest jedna oddzielna w mieście Małogoszczu w karczmie do probostwa należącej, druga we wsi Popowicach do funduszów probostwa nadanej. Pierwsza $z$ nich do skarbu zainkamerowana została.

${ }^{23}$ Por. przyp. 12. 
Stawy i młyny

O jedna ćwierć mili od miasta Małogoszcza był niegdyś staw mały Jawór zwany, lecz teraz zaniedbany i zarośnięty i żadnego użytku nie daje.

\section{Młyn}

O jedna ćwierć mili od miasta Małogoszcza znajduje się młynek do funduszów probostwa należący, na małej rzece od Kozłowa ze źródeł biorący swój początek.

\section{$\underline{\text { Lasy }}$}

Probostwo posiada swój las po większej części sosnowy, a mniejszej dębowy, o ćwierć mili od miasta Małogoszcza odległy, zostaje pod dozorem Urzędu Leśnego Małogoszcz, i z tego rok rocznie przeznaczoną zostaje według ustanowionej przez rząd ilości poręba na potrzeby proboszcza wystarczajaca.

\section{$\underline{\text { Folwarki i wsie do probostwa należace }}$}

Wieś Popowice zwana, w której jest folwark należacy do funduszów probostwa w Małogoszczu, odległa o mil dwie, w okręgu jędrzejowskim powiecie kieleckim guberni radomskiej. Włościanie tej wsi odrabiają pańszczyznę do folwarku w Popowicach do probostwa należącego.

\section{$\underline{W}[e]$ wsi Popowicach własność ziemi}

Grunta w[e] wsi Popowicach po większej części są piaszczyste, [k. 48] małej jednak ilości znajduja się rędziny lekkie.

\section{$\underline{\text { Łaki }}$}

Łąki są ciągle ponad rzeką Nidą, po większej części bagniste i mokre.

Mineralia. W gruntach do wsi Popowice należących mineraliów nie ma żadnych.

\section{$\underline{\text { Rzeki znaczniejsze }}$}

Przez grunta i łąki wsi Popowice przechodzi rzeka Nida, miejscami odznacza granice od wsi Popowice należace. 


\section{Stawy i młyny}

Stawu nie ma żadnego, jednak znajduje się młyn na rzece Nidzie w pobliskości wsi Popowice położony.

\section{Lasy}

Do folwarku wsi Popowice należy las sosnowy w bliskości wsi Popowice położony, pod dozorem Urzędu Leśnego Małogoszcz zostajacy, i z tego rok rocznie przeznaczona zostaje poręba według ilości przez rząd ustanowionej, jednak na potrzeby folwarczne wystarczająca.

\section{Dochody funduszów probostwa stanowiace}

1. Grunta orne i łaki.

2. Pańszczyzna od poddanych w mieście Małogoszczu znajdujacych się.

3. $Z$ młyna pod miastem Małogoszczem.

4. $Z$ propinacyi w mieście Małogoszczu.

5. W[e] wsi Popowicach z gruntów i łak.

6. $Z$ propinacyi w[e] wsi Popowicach.

7. $Z$ młyna do wsi Popowice należącego.

8. Z pańszczyzny od poddanych w[e] wsi Popowicach znajdujących się.

\section{Dziesięciny pieniężne}

a. Dziesięcina pieniężna $z$ miasta Małogoszcza według aktu zamiany przez b. [yła] Komisyja Rzadowa Wyznan Religijnych [i] Oświecenia Publicznego z dnia 28 marca 1825 roku № $\frac{2995}{570}$, [k. 48v] zatwierdzonego do lat dwudziestu pięciu rocznie po złotych polskich sześćset N. zp. 600, później żyta po korcy czterdzieści pięć N. 45.

b. Dziesięciny folwarczne wsi Ciesiel i Leśnica wedle aktu przez Komisyja Rzadowa W.[yznań] R.[eligijnych] [i] O.[świecenia] Publicznego $z$ dnia 11 listopada 1819 r. № 6516 zatwierdzonego złotych polskich pięćdziesiąt ośm groszy N. zp. 58 gr 8 . 
c. Dziesięcina od włościan wsi Ciesiel wedle aktu jak wyżej z daty i numeru zatwierdzonego złotych polskich dwieście piętnaście groszy ośmnaście N. zp. 215 gr. 18.

d. Od włościan wsi Leśnicy wedle aktu jak wyżej zatwierdzonego złotych polskich sto ośmdziesiąt cztery groszy ośm i trzy dziesiąte N. zp. 184 gr. 8.

e. Dziesięcina $z$ dworu Lasochów od najdawniejszych czasów opłacana bywa w pieniądzach i do dziś dnia zł pol. sto N. zp. 100 rocznie opłaca.

f. Dwór sołtystwa Gnieździsk wedle resk[ryp]tu Komisyji Województwa Krakowskiego z dnia 16 września 1822 r. N. 23216 złotych polskich dwadzieścia siedem i grosz jeden N. zp. 27 gr 1.

g. Wieś Popowice, lubo dziesięcina, czyli zamieniona od gromady tejże wsi należąca, nie masz żadnego śladu, jednak od lat przeszło dwudziestu sześciu dziesięcinę opłacaja proboszczowi w pieniądzach rocznie złotych polskich trzydzieści sześć N. zp. 36.

\section{Dziesięciny w zbożu}

Dziesięcina $z$ dworu Bolmin według aktu przez b.[yła] Komisyją Rządową Wyznań Religijnych [i] Oświecenia Publicznego z dnia 10 lipca 1820 r. N. 3138 zatwierdzonego, żyta korcy jedynaście garncy dwadzieścia sześć N. kor. 11 gar. 26.

Dziesięcina dworska $z$ wójtostwa rządowego Małogoszcz według aktu p[rzez] byłą Komisyją Rządową Wyznań Religijnych [i] Oświecenia Publicznego z dnia 12 kwietnia 1826 r. N. zatwierdzonego, żyta korce jeden garncy ośmnaście N. kor. 1 gar. 18 .

Dziesięcina gromadzka od włościan wsi Gnieździsk do probostwa [k. 49] należących według reskryptu Komisyji Województwa Krakowskiego z dnia 16 września 1822 r. N. 23216 żyta korcy trzy garncy ośm N. kor. 3 gar. 8.

\section{Sumy kapitalne na dobrach lokowane}

Na dobrach Kozłów suma kapitalna złotych polskich tysiąc N. zp. 1000, od której pobierany bywa procent zp. $40 \mathrm{z}$ kasy powiatowej.

$\mathrm{Na}$ dobrach Żytnie gubernii warszawskiej ulokowana suma kapitalna zp. dwa tysiace N. zp. 2000, od tego jednak kapitału procent się nie pobiera. 
Granice gruntów, lasów, łak do probostwa należących

Grunta folwarczne do probostwa należące w Małogoszczu granicza $z$ gruntami mieszczan tegoż miasta, $z$ gruntami do wójtostwa Małogoszcza należącymi i z lasami dóbr prywatnych Kozłowa.

\section{Granice wsi Popowice do probostwa należacej}

Grunta folwarczne wsi Popowice granicza $z$ dobrami prywatnymi Oksa od zachodu, od wschodu $z$ dobrami prywatnymi Tyniec, łaki granicza $z$ dobrami prywatnymi Nagłowice i dobrami rząow[ymi] Cierno. Lasy granicza z dobrami Tyniec, Węgleszyn i Oksa. Włościanie wsi Popowice maja grunta i łąki osobno oddzielone.

\section{Ludność parafii}

\begin{tabular}{|c|c|c|c|c|c|c|}
\hline \multicolumn{2}{|c|}{ Nazwisko } & \multirow{2}{*}{$\begin{array}{c}\text { W czyjem } \\
\text { jest posia- } \\
\text { daniu }\end{array}$} & \multirow{2}{*}{$\begin{array}{c}\begin{array}{c}\text { Odległość } \\
\text { od kościoła }\end{array} \\
\text { mile }\end{array}$} & \multicolumn{3}{|c|}{ Ilość dusz } \\
\hline gminy & $\begin{array}{c}\text { wsi } \\
\text { i miasta }\end{array}$ & & & chrześcijan & Żydów & razem \\
\hline $\begin{array}{l}\text { Miasto } \\
\text { Mało- } \\
\text { goszcz }\end{array}$ & $\begin{array}{l}\text { Mało- } \\
\text { goszcz }\end{array}$ & rządowe & $\mathrm{w}$ miejscu & 1091 & - & 1091 \\
\hline Cieśle & Cieśle & rządowe & $\begin{array}{l}\text { ćwierć } \\
\text { mili }\end{array}$ & 220 & 6 & 226 \\
\hline Cieśle & Skorków & rządowe & $\begin{array}{l}\text { trzy ćw. } \\
\text { mili }\end{array}$ & 231 & 3 & 234 \\
\hline Cieśle & Leśnica & rządowe & $\begin{array}{l}\text { ćwierć } \\
\text { mili }\end{array}$ & 101 & - & 101 \\
\hline Ruda & Ruda & rządowe & $\begin{array}{l}\text { mila } \\
\text { jedna }\end{array}$ & 47 & 5 & 52 \\
\hline Ruda & $\begin{array}{l}\text { Zajacz- } \\
\text { ków }\end{array}$ & rządowe & $\begin{array}{l}\text { mila } \\
\text { jedna }\end{array}$ & 484 & 5 & 489 \\
\hline Ruda & Wesoła & rządowe & $\begin{array}{l}\text { mila } \\
\text { jedna }\end{array}$ & 52 & - & 52 \\
\hline Ruda & Młynki & rządowe & $\begin{array}{l}\text { mila } \\
\text { jedna }\end{array}$ & 25 & - & 25 \\
\hline Ruda & $\begin{array}{l}\text { Gnieździ- } \\
\text { ska }\end{array}$ & rządowe & $\begin{array}{l}\text { mila } \\
\text { jedna }\end{array}$ & 305 & - & 305 \\
\hline
\end{tabular}




\begin{tabular}{|c|c|c|c|c|c|c|}
\hline \multicolumn{2}{|c|}{ Nazwisko } & \multirow{2}{*}{$\begin{array}{l}\text { W czyjem } \\
\text { jest posia- } \\
\text { daniu }\end{array}$} & \multirow{2}{*}{$\begin{array}{c}\begin{array}{c}\text { Odległość } \\
\text { od kościoła }\end{array} \\
\text { mile }\end{array}$} & \multicolumn{3}{|c|}{ Ilość dusz } \\
\hline gminy & $\begin{array}{c}\text { wsi } \\
\text { i miasta }\end{array}$ & & & chrześcijan & Żydów & razem \\
\hline Lasochów & Dwór & $\begin{array}{l}\text { Wo Stoj- } \\
\text { noskiego }\end{array}$ & $\begin{array}{l}\text { mila } \\
\text { jedna }\end{array}$ & 20 & - & 20 \\
\hline \multicolumn{4}{|l|}{ w ogóle } & & & 2595 \\
\hline
\end{tabular}

[k. 49v] Okoliczne parafie sa

Rembieszyce, Złotniki Węgleszyn, Kozłów, Krasocin i Bolminc.

[k. 65v] Opisanie

budowli probostwa i zabudowań do niego należacych

\section{Mieszkanie proboszcza}

Całkiem $z$ kamienia murowane, mury od strony zachodniej, a więcej jeszcze od wschodniej sa popękane, dach gontami kryty od strony północnej w złym, reszta w dosyć dobrym stanie, kominy nad dach wyprowadzone dwa od fundamentów murowane, front od południa piętrowy, od północy parterowy. Od strony północnej wchód jest $z$ cmentarza przez drzwi sosnowe fasowane ${ }^{24}$ na zawiasach i hakach żelaznych, $z$ zasuwa, skoblem i wrzeciądzem. Sień kamieniem wybrukowana, powała na belkach służy zarazem za podłogę na strychu, $z$ sieni ida schody na strych tarcicami obite i drzwiami sosnowymi na zawiasach i hakach $z$ zamkiem opatrzone. Po prawej stronie sieni sa drzwi sosnowe do stancyi na hakach i zawiasach żelaznych, zamek francuski z kluczem zły. W tej stancyi jest podłoga $z$ tarcic w stanie zupełnie złym, powała bez sufitu. Okno krata żelazną opatrzone. W tej stancyi sa dwie komórki $z$ drzwiami sosnowymi zamykane na zawiasach i hakach, z zamkiem bez kluczy, w obydwu komórkach sa okienka małe, krata

\footnotetext{
b Odczyt jedynie prawdopodobny.

c Dalej następuje „Opisanie kościoła i jego ozdób”, będące przedmiotem osobnej edycji. Por. M. Karkocha, Wystrój i wyposażenie kościoła..., s. 325-330 (uwagi wstępne), 331-360 (tekst źródłowy).
}

${ }^{24}$ Fasowane - uszczelnione, zabezpieczone. 
żelazna opatrzone, pomiędzy komórkami jest framuga duża, również jak i komórki sklepiona - w pokoju tym jest komin zwalony, a pieca brakuje. $Z$ pokoju tego sa drzwi sosnowe na zawiasach i hakach, $z$ zamkiem francuskim starym i haczykiem żelaznym do pokoju frontowego, w którym jest podłoga stara, powała bez sufitu, piec stary, wymagajacy przestawienia, i kominek, dwa okna dubeltowe. $Z$ pokoju tego po dwóch schodach wchodzi się przez drzwi sosnowe na zawiasach i hakach, $z$ zamkiem [k. 66] francuskim do sali, w której jest podłoga stara, znacznej jednak części podłogi brakuje, pieca nie ma, powała bez sufitu. Okna pojedyncze bez ferklajdunku ${ }^{25}$. W tejże sali sa drugie drzwi do sieni na zawiasach i hakach, $z$ zamkiem francuskim starym, a trzecie drzwi podwójne, $z$ których jedne na zawiasach i hakach, a drugie podwójne na zawiasach francuskich $z$ zasuwami i zamkiem francuskim; drzwiami tymi wchodzi się do pierwszego pokoju, w którym jest podłoga stara, sufit, kominek, piec kaflowy i następna stancyją ogrzewajacy, okna dubeltowe; $z$ tego pokoiku sa drugie drzwi małe prowadzace do szpichlerza, na zawiasach i hakach, $z$ zamkiem francuskim, $z$ dwoma haczykami, i drugie drzwi podwójne na zawiasach francuskich, $z$ zamkiem francuskim, bez klucza, zdezelowane; drzwi te prowadzą do ostatniego pokoiku, w którym jest podłoga dosyć dobra, sufit i okna dubeltowe.

$Z$ pokoiku poprzedniego drzwiczkami wyżej opisanymi wchodzi się do spichlerza wąskim korytarzykiem, w którym jest podłoga zupełnie zła i sklepienie. $Z$ korytarzyka tego wchodzi się na korytarz poprzeczny, w którym również, jak i w całym spichrzu jest podłoga zła, tak dalece, że zboże się przez szpary przesypuje. Spichlerz ten przedzielony jest na dwie części, z których w każdej znajdują się trzy sąsieki. Od frontu spichlerza tego sa drzwi wychodzace na cmentarz na zawiasach i hakach, $z$ zasuwa drewniana, [k. 66v] skoblem i wrzeciądzem. $Z$ sieni piętrowej są drzwi żelazne do lamusa, który jest sklepiony, brukowany, $z$ oknem bez szkła, żelazna kratą opatrzony. Do lamusa tego sa drzwi żelazne na hakach i zawiasach ze skoblami.

Z sieni piętrowej wyżej opisanej po schodach drewnianych bardzo złych i sklepionych, schodzi się do sieni dolnej, w której od samego frontu sa drzwi sosnowe na zawiasach i hakach, $z$ skoblem i wrzeciądzem. Sień ta jest kamieniem brukowana, $z$ powała i jed-

${ }^{25}$ Ferklajdunek - rama $z$ szerokiej listwy naokoło okna lub drzwi. Por. M. Arcta, Słownik ilustrowany języka polskiego, t. I, Warszawa 1916, s. 308. 
nym małym oknem. $Z$ sieni tej na wschodniej stronie sa drzwi na zawiasach i hakach, $z$ skoblem i wrzeciądzem oraz $z$ zamkiem bez klucza do pokoiku sklepionego, $z$ podłoga stara, $z$ piecem murowanym $z$ cegły i kominem oraz oknem starym. $Z$ pokoiku tego wchodzi się drzwiami sosnowymi na zawiasach i hakach skoblem i wrzeciądzem do podłużnego trójkatnego alkierza, w którym jest podłoga zupełnie zła i powała oraz dwa okna deskami zabite. $Z$ alkierza tego wchodzi się do pierwszej piwnicy niesklepionej, w której po prawej stronie jest podobnież piwnica bez sklepienia, a po lewej jest [.] ${ }^{\mathrm{d}}$ wejście drzwiami sosnowymi na hakach i zawiasach, [ze] skoblem i wrzeciądzem do piwnicy sklepionej, z legarami i stołem ordynaryjnym. $Z$ dolnej sieni jest drugie wnijście do piwnicy, znajdującej się pod schodami i pod sienia piętrową. Do tej piwnicy są drzwi na zawiasach i hakach ze skoblem i wrzeciądzem, piwnica ta jest sklepiona. $Z$ tejże sieni w stronie zachodniej jest kuchnia, do której jest wnijście drzwiami [k. 67] zupełnie złymi, na zawiasach i hakach. W kuchni komin i szabacznik wymagaja koniecznego przestawienia, podłogi nie ma, powała $z$ tarcic i dwa okna małe.

$Z$ kuchni jest wnijście drzwiami również złymi na zawiasach [ze] skoblem i wrzeciądzem do piwnicy sklepionej. Cały dom proboszczowski w ogólności jest w stanie dosyć dobrym. Wartość: 860 rs.

\section{Mansjonaria}

$Z$ byłej mansjonaryi pozostały się obecnie same tylko mury, z których ściana od zachodu ze wszystkim się zawaliła, zaś ściana od wschodu jest od samego wierzchu aż na dół pęknięta, tak że cała część północna grozi upadkiem, i jako niebezpieczna dla przejeżdżających przeznaczona jest ażeby siłą szarwarku rozebrana została ${ }^{\mathrm{e}}$.

\section{Folwark na pomieszczenie czeladzi}

W dziedzińcu probostwa znajduje się folwark $z$ drzewa rżniętego w węgieł, gontem pokryty, dosyć dobry, komin murowany. Do sieni sa drzwi na zawiasach i hakach, ze skoblem i klamka. W sieni

\footnotetext{
d Słowo skreślone.

e W „Uwagach” zanotowano: „Mansjonarię tę zastał ks. Świątkowski jakkolwiek w złym stanie, jednak zamieszkalna - nie wiadomo $z$ jakich powodów samowolnie ją rozebrał, materiał zniszczył, a mury w gruzach pozostawił”.
} 
tej podłogi nie ma, powała $z$ tarcic, nad cała powała znajduje się polepa. $Z$ sieni tej po lewej stronie sa drzwi na zawiasach i hakach, z klamka, skoblem i wrzeciądzem. Drzwiami tymi wchodzi się do izby, w której jest podłoga stara, komin, szabacznik, piec z cegły, ogrzewajacy dwie stancyje, powała $z$ tarcic, okna dwa. $Z$ tej izby wchodzi się do drugiej, mniejszej, drzwiami na zawiasach i [z] wrzeciądzem. W tej izbie również ${ }^{\mathrm{f}}$ również ${ }^{\mathrm{f}}$ jest podłoga stara i okno wychodzace na ogród, stąd wchodzi się znowu do małego [k. 67v] alkierza drzwiami na zawiasach i hakach, [ze] skoblem i wrzeciądzem. W alkierzu tym jest podłoga i powała $z$ tarcic i okienko małe. $Z$ drugiej strony sieni jest wnijście drzwiami na zawiasach i hakach, z klamka do izby czeladniej, w której podłogi nie ma, powała $z$ tarcic, komin, szabacznik i piec i trzy okna. $Z$ izby tej jest drzwi troje do trzech komórek na zawiasach, hakach, $z$ wrzeciądzami i skoblami, w komórkach podłogi nie ma, powała jest $z$ tarcic i małe okienka. Folwark cały w ogólności jest w stanie dosyć dobrym. Wartość: 130 rs.

Stajnie i chlewy. W jednej linii $z$ folwarkiem znajduje się zabudowanie ${ }^{g}$ mieszczace w sobie: a) stajnię, do której są drzwi podwójne na biegunach $z$ wrzeciądzem. W stajni tej podłoga przegniła, stara, żłoby dobre, drabiny dobre, powała $z$ rozmaitych kawałków. W stajni tej znajduje się komórka na sieczkę i obrok ${ }^{\text {h }}$; b) za stajnia jest obora dla bydła, w której podobnie podłoga stara przegniła, powała $z$ różnych kawałków, żłoby złe i drabiny; c) w końcu samym jest przegroda na paszę, bez podłogi i z powała ${ }^{i}$. Całe zabudowanie w ścianach jest dosyć dobre, dach w stanie złym; d) naprzeciwko tego zabudowania znajduje się zabudowanie drugie, drewniane, w słupy postawione, gdzie mieści się: $1^{\circ}$ skład na narzędzia gospodarskie, w którym podłoga $z$ okraglaków i powała, do składu tego wrótka podwójne ze skoblem i wrzeciądzem. Następnie są cztery chlewiki dla trzody, do których jest wnijście spod wystawy ${ }^{\mathrm{j}}[\mathrm{k}$. 68] z czteroma drzwiami na biegunach, ze skoblami i wrzeciądzami. Wartość: 270 rs.

f-f Powtórzone słowo.

g Dopisano obok tą samą ręką: „w węgieł postawione, słoma pokryte”.

h Dopisano z boku tą samą ręką: „do której są drzwi z skoblem i wrzeciądzem”.

i Dopisano obok tym samym charakterem pisma: „drzwiami na biegunach ze skoblem i wrzeciądzem".

j Odczyt jedynie prawdopodobny. 
Spichlerz, który mieścił się w dziedzińcu probostwa, został pożarem zniszczony, nie wiadomo, czy były beneficjat należytość z Dyrekcji Ubezpieczeń odebrał lub nie ${ }^{\mathrm{k}}$.

Stodoły. Poza stajniami znajduje się zabudowanie wokół stawiane, w którym mieszcza się od wschodu i zachodu dwie duże stodoły, naprzeciwko siebie postawione w słupy, wyjąwszy jednego zapola w węgieł zbudowanego. Obie stodoły poszyte sa słoma, w stanie miernym. W obydwóch stodołach znajdują się po dwa klepiska $z$ ośmiu wrotami na biegunach, do czterech wrót frontowych są skoble i wrzeciądze. W obydwu również stodołach znajdują się po trzy zapola, jedne wśród klepiska, dwa po bokach. Pomiędzy stodołami od strony południowej jest zabudowanie drewniane w słupy stawiane, gontami pokryte, w którym mieści się: a) wozówka, do której sa wrota na biegunach, ze skoblem i wrzeciądzem, bez podłogi, i powała $z$ różnych kawałków; b) komora na skład różnych materiałów, $z$ podłoga i powałą, do której sa drzwi na zawiasach, [ze] skoblem i wrzeciądzem; c) spichlerzyk, do którego są drzwi na zawiasach, [ze] skoblem i wrzeciądzem, z podłoga i powała, $z$ trzema sąsiekami. Naprzeciwko tego zabudowania również między stodołami jest szopa słoma poszyta. Wartość: 480 rs.

[k. 68v] Ogród fruktowy. Wprost dziedzińca probostwa jest ogród fruktowy wzdłuż łokci 180, wszerz łokci 90. Drzewa w tym ogrodzie różnego rodzaju: gruszki, jabłka, śliwki, wiśnie, jeden kasztan dziki, drzewa po większej części stare, mniej użytku przynoszą.

Ogrodzenie sadu i całego dziedzińca proboszczowskiego jest $z$ żerdzi w stanie złym po największej części. Brama wjazdowa od frontu probostwa zupełnie zła, zaś z tyłu probostwa przy stodołach znajduje się kołowrót. Całe probostwo wymaga nowego ogrodzenia, ponieważ zewsząd jest przystępne nie tylko dla przechodzących, ale i jeżdżących.

Karczma do probostwa niegdyś należąca dziś do rządu inkamerowana została, z której proboszcz ma przyznaną kompetencją. Wartość: 160 rs.

\footnotetext{
k Dopisano obok w „Uwagach” inną ręką: „Ze spichlerza tego właściwie tylko jeden narożnik się spalił, resztę zaś całkowicie zabudowanie rozebrał samowolnie ks. Światkowski”.
} 
Browar niegdyś mieszczący się w ogrodzie fruktowym, dziś zupełnie nie istniejel.

Młyn pod Jaworem zwany. Zabudowanie młyna $z$ drzewa obrabianego $\mathrm{w}$ węgieł stawiane, pomieszkanie młynarza i młyn pod jednym dachem $z$ gontów, $z$ kominem murowanym. Do sieni jest drzwi dwoje na przestrzal, ze skoblami i wrzeciądzami, sień bez podłogi i powały, po jednej stronie jest wchód do młyna, drzwi ze skoblem i wrzeciądzem, podłogi ani powały nie ma. W młynie kamień wierzchni i spodni, kosz, skrzynia, koło wodne i palczate na wale, po obydwu końcach refowane, z żelazem, z czopami. Oprócz tego w młynie urzadzony jest jagielnik, upust w stanie dobrym. Do izby mieszkalnej młynarza naprzeciwko młyna sa drzwi [k. 69] na zawiasach i hakach, $z$ skoblem i wrzeciadzem, w izbie podłoga i powała, komin, szabacznik i piec, okna trzy. $Z$ tej izby sa drzwi na zawiasach i hakach, $z$ skoblem i wrzeciądzem, bez podłogi, $z$ powałą. $Z$ komory sa drzwi na podwórze na biegunach, na zasuwę drewnianą zamykane. Żadnych narzędzi młynarskich nie ma do probostwa należących. Całe zabudowanie młynarza powyżej opisane jest w stanie dość dobrym. Wartość: 130 rs.

Stodoła. Naprzeciwko młyna stoi stodoła w węgieł postawiona, słoma pokryta, wrota na przestrzał na biegunach, klepisko, z dwoma zapolami. Cała stodoła jest w stanie dość dobrym. Wartość: 30 rs.

Chlewy i chlewiki sa ze wszystkim tak złe, że nawet drzewo mało ma wartości, przeto nie opisuja się jako wymagajace koniecznie rozebrania i postawienia na nowo. Wartość: 40 rs.

\section{Chałupy za sadem proboszczowskim}

Pierwsza od drogi chałupa podwójna w węgieł zbudowana, w połowie gontem, a w połowie słoma pokryta. Po obydwu końcach są sienie, $z$ których wchodzi się do izb, z tą różnicą, że w drugiej części jest jeszcze $z$ izby komora. Wszystkie drzwi są na biegunach, ze skoblami i wrzeciądzami. Komin murowany nad dach, w obydwu izbach sa kominy i szabaczniki, i po jednym oknie, powały

${ }^{1}$ Dopisano obok w „Uwagach” inna ręką: „Browar ten jest w stanie złym, lecz przez ks. Świątkowskiego został [?] rozebrany”. 
sa $z$ tarcic w izbach i komorach, lecz podłogi nigdzie nie ma. Cała chałupa w dość dobrym stanie. Wartość: 30 rs.

Następna chałupa również podwójna, podobna zupełnie do poprzedniej, $z$ tą różnica, że [k. 69v] dach cały jest gontem pobity, i że w obydwu izbach sa komory. Wartość: 50 rs.

Trzy stodoły. Dla trzech zagrodników w powyżej wymienionych chałupach mieszkalnych znajduja się przed oknami trzy stodoły w słupy postawione, słoma pokryte, każda słoma pokryta. Każda po dwa zapola o jednym klepisku, po jednych wrotach na biegunach, ze skoblami i wrzeciądzami, w dosyć dobrym stanie. Wartość: 30 rs.

Obórki. Nadto dla każdego zagrodnika przybudowana jest przy chałupie obórka w słupy stawiana, pokryta gontem i dotykająca węgłów chałupy.

Chałupa poczwórna na Ściegnach. W końcu ulicy Włoszczowskiej postawiona jest chałupa poczwórna, w węgieł zbudowana, gontem pokryta, $z$ kominem wymurowanym nad dach wyprowadzonym. W jednej sieni w środku chałupy, z której po obydwu stronach jest wnijście do czterech izb, a $z$ każdej izby jest komora, w każdej izbie znajduje się piec służący zarazem za komin, podłogi nigdzie nie ma, nad izbami i komorami sa powały i po jednym oknie. Drzwi frontowe do sieni czworo, drzwi do izb sa na zawiasach i hakach ze skoblami i wrzeciądzami, reszta drzwi na biegunach. Cała chałupa jest w stanie dobrym. Wartość: 80 rs.

Chałupa pod Sabianowem. Pod lasem proboszczowskim Sabianów zwanym jest chałupa podwójna dla zagrodnika i dla gajowego. Chałupa dla [k. 70] gajowego poniewczasie się ze wszystkim zawaliła, a nawet drzewo w większej części rozkradzione zostało, przeto się nie opisuje, część zaś dla zagrodnika jest w węgieł postawiona, słupami popodpierana, słoma poszyta, $z$ kominem nad dach wymurowanym, do obydwu izb służącym. Składa się $z$ sieni, $z$ izby i komory, wszystkie drzwi sa na biegunach, okno jest w izbie jedno większe, a drugie mniejsze na tył wychodzące, podłogi nigdzie [nie] ma, powała jest ponad izba i komorą. Cała chałupa jest w stanie najgorszym i zagraża bardzo bliskim zawaleniem się, do tej chałupy $^{\mathrm{m}}$ stodoła jest o dwóch zapolach, jednym klepiskiem i jednych

\footnotetext{
${ }^{\mathrm{m}}$ Słowo nadpisane nad wierszem.
} 
wrotach, w słupy postawiona i słoma poszyta, wrota sa na biegunach ze skoblem i wrzeciądzem. Stodoła ta jest w dosyć dobrym stanie. Pomiędzy chałupa a stodoła jest obórka, również w słupy postawiona, i tak jak chałupa w najgorszym stanie. Wartość: 50 rs.

\section{Opisanie \\ gruntów, łak i lasów do probostwa należacych}

Podług inwentarza pomiarowego w r.[oku] 1822 przez geometrę rządowego sporządzonego, probostwo w Małogoszczu posiada gruntów i łąk i lasów wielości następującej.

Gruntu pszennego w bliskości kościoła probostwa położonego miary polskiej morgów dziewięćdziesiąt sześć N. 96 prętów sto sześćdziesiąt jeden N. 161.

Gruntu piaszczystego od dawna $z$ lasów wyrobionego pomiędzy zaroślami do probostwa należącymi w różnych miejscach położonych, między granicami dóbr Żarczyc Większych, Lasochowem, [k. 70v] niemniej miejskimi, w ogóle morgów sto dwadzieścia cztery N. 124 prętów sześćdziesiąt jeden N. 61.

Łakka pagórkowa pod Babinkiem zwana mogrów dwie N. 2 prę.[tów] sto trzydzieści sześć N. 136.

Zarośli do probostwa należących w ogóle morgów pięćset jeden N. 501 prę.[tów] dwieście trzydzieści sześć.

\section{Co do gruntów zagrodników}

do probostwa w Małogoszczu należacych

Zagrodnicy proboszczowscy nie mają osobno wydzielonych gruntów, ogrodów i łąk, maja jednak udzielone spomiędzy gruntów do probostwa należących, za używanie takowych pańszczyznę odrabiają.

\section{$\underline{\text { Spis }}$}

zagrodników i komorników do probostwa w Małogoszczu

\section{pańszczyzne odrabiajacych}

Zagrodników jest czterech N. 4. Odrabiają pańszczyzny po dni pieszych trzy N. $3 \mathrm{w}$ tygodniu.

Komorników trzech N. 3. Odrabiają pańszczyzny po jednym dniu N. 1 pieszym w tygodniu. 


\section{Co do szpitala}

Całe zabudowanie szpitalne oraz fundusze i grunta do tegoż szpitala należące, niemniej i opieka nad ubogimi obecnie według ogólnego prawa krajowego należy do Dozoru Parafialnego, przeto $\mathrm{w}$ tym miejscu się takowe nie opisuje.

\section{$\underline{\text { Szkoła elementarna }}$}

W mieście Małogoszczu znajduje się szkoła elementarna. Po zburzeniu mansjonarii zakupiony został przez miasto oddzielny na pomieszkanie nauczyciela oraz i na szkołę elementarną, w której pobierają naukę dzieci miejskie płci obojej. Nauczyciel utrzymuje się ze składek mieszczan oraz $z$ ogrodu, ze strony proboszcza miejscowego dodanego i rowem od pastwiska oddzielonego, któren obejmował morge polska jedna. Nominacja nauczyciela należy według ogólnego prawa do Kuratorii, proboszcz zaś jest tylko opiekunem szkoły ${ }^{\mathrm{n}}$.

[k. 71] Opis

kmieci, zagrodników i komorników w[e] wsi Popowicach

i ich obowiazki

\begin{tabular}{|c|c|c|c|c|}
\hline & \multirow{2}{*}{ Wyszczególnienie włościan } & \multicolumn{2}{|c|}{$\begin{array}{l}\text { Ile dni w tydzień } \\
\text { winien odrabiać }\end{array}$} & \multirow[t]{2}{*}{ Uwagi } \\
\hline & & ciagłych & pieszych & \\
\hline 1 & $\frac{\underline{\text { Kmiecie }}}{\text { Kmieci dwóch odrabiają po dni } 4}$ & 8 & & \\
\hline 2 & $\begin{array}{l}\qquad \text { Zagrodnicy } \\
\text { Zagrodników siedmiu, których każ- } \\
\text { dy odrabia po dni trzy razem }\end{array}$ & & 21 & \\
\hline 3 & $\begin{array}{l}\text { Komornicy } \\
\text { Komorników trzech odrabiajacych } \\
\text { po jednym }[\mathrm{k} .71 \mathrm{v}] \text { dniu pieszym } \\
\text { razem }\end{array}$ & & 3 & \\
\hline & $\begin{array}{l}\text { W innych trzech izbach komornych } \\
\text { mieści się czeladź dworska }\end{array}$ & & & \\
\hline
\end{tabular}

${ }^{\mathrm{n}}$ Dalej sześć kartek wyrwanych (s. 49-60 według pierwotnej numeracji). 


\begin{tabular}{|c|c|c|c|}
\hline \multirow{2}{*}{ Wyszczególnienie włościan } & \multicolumn{2}{|c|}{$\begin{array}{l}\text { Ile dni w tydzień } \\
\text { winien odrabiać }\end{array}$} & \multirow[t]{2}{*}{ Uwagi } \\
\hline & ciagłych & pieszych & \\
\hline $\begin{array}{l}\text { Daniny } \\
Z \text { dawnych danin obecnie podług ta- } \\
\text { beli prestacyjnej }{ }^{26} \text { pozostały się przę- } \\
\text { dzenie. Kmiecie przędą po łokci dwa- } \\
\text { naście, zagrodnicy po łokci sześć. } \\
\text { Prócz pańszczyzny powyżej wymie- } \\
\text { nionej powyżsi włościanie winni od- } \\
\text { rabiać do żniwa dwie powaby }{ }^{27} \text {, to jest } \\
\text { jedne do oziminy, drugą do jarzyny. }\end{array}$ & & & \\
\hline $\begin{array}{l}\text { Wiadomość co do Popowic } \\
\text { O inwentarzach włościańskich nie- } \\
\text { mniej o gruntach przez nich posia- } \\
\text { danych, na ostatek ilość zaprowa- } \\
\text { dzonych dla nich zasiewów }\end{array}$ & & & \\
\hline
\end{tabular}

\section{[k. 72] Co do inwentarzy}

Pierwszy $z$ kmieci przy odbieraniu gospodarstwa ma sobie oddane: parę koni, parę wołów roboczych, pług kompletny z żelazami, parę kółek do pługa obrysowanych, jedno radło $z$ radlicą żelazna, jarzmo na woły $z$ wiciami żelaznymi.

Drugi kmieć przy odbieraniu gospodarstwa ma sobie oddane: parę koni, parę wołów roboczych, wóz bosy, pług kompletny z żelazami, parę kółek do pługa obrysowanych, radło $z$ radlica żelazna, bron para jedna $z$ broniakami żelaznymi, jedno jarzmo $z$ wiciami żelaznymi.

${ }^{26}$ Tabela prestacyjna - spis gospodarstw chłopskich w Królestwie Polskim, sporządzony na mocy dekretu cara Mikołaja I z 7 VI 1846 r., zawierający nazwisko gospodarza, obszar i podział gruntów, jak również obciążenia i uprawnienia użytkowników. Sporządzenie tabel prestacyjnych miało zahamować rugi chłopskie i przyczynić się do zmniejszenia i uregulowania powinności chłopów na rzecz dworu. Więcej na ten temat por. T. Mencel, Wieś pańszczyźniana w Królestwie Polskim w połowie XIX wieku, Lublin 1988, s. 17 i n. O wartości tego źródła $\mathrm{w}$ badaniach historycznych pisał m.in. Z. Stankiewicz, Tabele prestacyjne jako źródło wiadomości o przemianach wsi Królestwa Polskiego w połowie XIX wieku, „Przegląd Historyczny” 1962, t. LIII, z. 2, s. 311 i n.

27 Powaba (także „gwałty”, „tłoki”) - dodatkowa forma pańszczyzny w dawnej Polsce. Chłop świadczył ja na wezwanie dworu w okresach natężonych prac polowych, zazwyczaj w wymiarze od pięciu do $10 \mathrm{dni}$ w roku na wiosnę (powaba wiosenna) i na zimę (powaba zimowa). 


\section{Co do ilości gruntów}

Każdy kmieć w[e] wsi Popowicach ma oddzielonego osobno gruntu po mogrów ośmnaście i prętów sześć. Każdy zaś zagrodnik w[e] wsi Popowicach ma oddzielonego osobno gruntu po morgów dwanaście i prętów trzy.

\section{Co do ilości obsiewów}

Każdy kmieć przy objęciu gospodarstwa odebrał grunta obsiane w ilości następującej: pszenicy korcy dwa garncy szesnaście, żyta korcy trzy, jęczmienia korcy dwa, owsa korcy trzy.

Każdy zaś zagrodnik przy odbieraniu gospodarstwa odebrał wysianego żyta korcy dwa, jęczmienia korzec jeden garncy ośm, owsa garncy dwadzieścia cztery.

\section{Co do łak}

Tak każdy kmieć w[e] wsi Popowicach, jako też i zagrodnik mają osobno oddzielone łąki, które do utrzymania inwentarza sa wystarczające. [k. $72 \mathrm{v}]$

\section{Wiadomości}

O obsiewach pro fundo instructo tak przy probostwie w mieście Małogoszczu, jako też wsi Popowicach prowent beneficjum w Małogoszczu stanowiących

\begin{tabular}{|c|l|c|r|l|}
\hline \multirow{2}{*}{ N.p. } & \multirow{2}{*}{$\begin{array}{c}\text { Wyszczególnienie } \\
\text { rzeczy }\end{array}$} & \multicolumn{2}{|c|}{ Ilość wysiewu } & \multirow{2}{*}{ Uwagi } \\
\cline { 3 - 5 } & worce & gar.[nce] & \\
\hline 1 & Pszenicy & 10 & - & Korcy dziesięć \\
\hline 2 & Żyta & 15 & - & Korcy piętnaście \\
\hline 3 & Jęczmienia & 7 & 18 & $\begin{array}{l}\text { Kor.[cy] siedm } \\
\text { gar.[ncy] ośmnaście }\end{array}$ \\
\hline 4 & Owsa & 19 & - & $\begin{array}{l}\text { Korcy dziewięt- } \\
\text { naście }\end{array}$ \\
\hline 5 & Grochu & 1 & $\begin{array}{l}\text { Kor.[cy] jeden } \\
\text { gar.[ncy] szesnaście }\end{array}$ \\
\hline
\end{tabular}




\begin{tabular}{|c|l|c|c|l|}
\hline \multirow{2}{*}{ N.p. } & \multirow{2}{*}{$\begin{array}{c}\text { Wyszczególnienie } \\
\text { rzeczy }\end{array}$} & \multicolumn{2}{|c|}{ Ilość wysiewu } & \multirow{2}{*}{ Uwagi } \\
\cline { 3 - 5 } & Tatarki & 4 & gar.[nce] & \\
\hline & $\begin{array}{c}\text { w[e] wsi } \\
\text { Popowicach }\end{array}$ & 18 & $\begin{array}{l}\text { Korcy cztery } \\
\text { gar.[ncy] ośm }\end{array}$ \\
\hline 1 & Pszenicy & 24 & - & Korcy ośmnaście \\
\hline 2 & Żyta & 7 & $\begin{array}{l}\text { Kor.[cy] dwadzie- } \\
\text { ścia cztery }\end{array}$ \\
\hline 3 & Jęczmienia & 1 & Korcy siedem \\
\hline 4 & Grochu & 18 & - & Korzec jeden \\
\hline 5 & Owsa & - & Korcy ośmnaście \\
\hline 6 & Prosa & & & Garncy ośm \\
\hline
\end{tabular}

\section{Wykaz}

inwentarza i ruchomości do probostwa w Małogoszczu

należacych, a przy spisaniu niniejszego inwentarza fundi instructi obecnie znalezionych

\begin{tabular}{|c|c|c|c|c|c|}
\hline \multirow[t]{2}{*}{ N.p. } & \multirow{2}{*}{$\begin{array}{l}\text { Wyszczególnienie } \\
\text { rzeczy }\end{array}$} & \multirow{2}{*}{$\begin{array}{l}\text { Przy spisa- } \\
\text { niu znale- } \\
\text { ziono }\end{array}$} & \multicolumn{2}{|c|}{$\begin{array}{l}\text { Wartość według } \\
\text { oszacow.[ania] }\end{array}$} & \multirow{2}{*}{ Uwagi } \\
\hline & & & rs. & $\mathrm{k}$. & \\
\hline 1 & $\begin{array}{l}\text { Koni para średnio rosłe po } \\
\text { rs. } 10 \text { kopiejek } 80 \\
\text { Razem }\end{array}$ & 2 & 21 & 60 & \\
\hline 2 & Wół jeden & 1 & 13 & 50 & \\
\hline \multirow[t]{2}{*}{3} & Wół drugi & 1 & 14 & 85 & \\
\hline & [k. 73] Co do ruchomości & & & & \\
\hline 1 & $\begin{array}{l}\text { Drabin nad dach probo- } \\
\text { stwa }\end{array}$ & 2 & - & 60 & \\
\hline 2 & $\begin{array}{l}\text { Stołów dużych sosno- } \\
\text { wych }\end{array}$ & 2 & 1 & 20 & \\
\hline
\end{tabular}




\begin{tabular}{|c|c|c|c|c|c|}
\hline \multirow{2}{*}{ N.p. } & \multirow{2}{*}{$\begin{array}{l}\text { Wyszczególnienie } \\
\text { rzeczy }\end{array}$} & \multirow{2}{*}{$\begin{array}{l}\text { Przy spisa- } \\
\text { niu znale- } \\
\text { ziono }\end{array}$} & \multicolumn{2}{|c|}{$\begin{array}{l}\text { Wartość według } \\
\text { oszacow.[ania] }\end{array}$} & \multirow{2}{*}{ Uwagi } \\
\hline & & & rs. & $\mathrm{k}$. & \\
\hline 3 & $\begin{array}{l}\text { Stołów mniejszych } \\
\text { sosnowych }\end{array}$ & 2 & - & 75 & \\
\hline 4 & Osęka żelazna & 1 & - & 15 & \\
\hline 5 & $\begin{array}{l}\text { Cebrzyk do noszenia } \\
\text { wody }\end{array}$ & 1 & - & 20 & \\
\hline 6 & Dzieża do chleba & 1 & - & 20 & \\
\hline 7 & Skopków do dojenia krów & 2 & - & 16 & \\
\hline 8 & Siekacz żelazny & 1 & - & 6 & \\
\hline 9 & Niecki do kapusty & 1 & - & 3 & \\
\hline 10 & Żeleźniak & 1 & - & - & \\
\hline 11 & Luszów & 1 & - & 20 & \\
\hline 12 & $\begin{array}{l}\text { Garniec browarniany } \\
\text { miedziany }\end{array}$ & 1 & 20 & - & \\
\hline
\end{tabular}

[k. 74v] Wykaz

czystej intraty probostwa małogoskiego wraz z[e] wsią Popowicami do tego probostwa należąca, stosownie do spisu świecko-duchownego pod dniem 6 kwietnia $1818 \mathrm{r}$.

Według spisu funduszów $z$ ro.[ku] 1818 ogólny dochód $z$ probostwa małogoskiego i $z[\mathrm{e}]$ wsi Popowic obliczonym został na złp 5136 gr 14 czyli na rs. 770 kop. 47.

Wydatek zaś na złp 3015 gr 11/4, czyli rs 452 kop. 258.

Więc czysty dochód wynosi złp 2121 gr 123/4, czyli rs 318 kop. $21 \%$.

Wyraźnie: rubli srebrem trzysta ośmnaście i kopiejek dwadzieścia jeden i trzy ósme. 


\section{Bibliografia}

\section{ŹRódeA ARCHIWALNE}

Archiwum Diecezjalne w Kielcach [ADK]

Akta konsystorskie ogólne. Życiorysy kapłanów 1835, sygn. OP-X/4b.

Akta konsystorskie ogólne. Życiorysy kapłanów 1835-1840, sygn. OP-X/3.

Akta konsystorskie. Status cleri 1847-1929, sygn. OP-X/13.

Akta personalne ks. Nestora Bierońskiego 1842-1890, sygn. XB-19.

Małogoszcz. Dokumenty różne z XIX wieku (luzem, nieuporządkowane), sygn. II PM-I/6, k. 105.

\section{Opracowania}

Achremczyk S., Marchwiński R., Przeracki J., Poczet biskupów warmińskich, Olsztyn 1994.

Arcta M., Słownik ilustrowany języka polskiego, t. I, Warszawa 1916, s. 308.

Borkiewicz S., Linowski Z., Monografia historyczna i gospodarcza ziemi jedrzejowskiej, Kielce 1937.

Giebartowski W., Ś.p. ks. Nestor Bieroński, „Przegląd Katolicki” 1899, R. XXXVII, nr 18, s. 281-284.

Hadamik C., Kalina D., Traczyński E., Miasto i gmina Małogoszcz [seria: Dzieje i zabytki małych ojczyzn, red. R. Mirowski], Kielce 2006.

Instrukcja wydawnicza dla źródeł historycznych od XVI do połowy XIX wieku, red. K. Lepszy, Wrocław 1953.

Karkocha M., Opis wizyty dziekańskiej kościoła parafialnego w Małogoszczu z roku 1830, „Przeglad Nauk Historycznych” 2016, R. XV, nr 2, s. 261-283.

Karkocha M., Parafia Rembieszyce 1438-2012. Studium z dziejów społeczności lokalnej, Łódź 2013.

Karkocha M., Uposażenie parafii Małogoszcz w świetle sumariusza z 1792 r., „Przegląd Nauk Historycznych” 2016, R. XV, nr 1, s. 249-276.

Karkocha M., Wystrój i wyposażenie kościoła parafialnego w Małogoszczu w świetle inwentarza z 1856 roku, „Przegląd Nauk Historycznych” 2017, R. XVI, nr 1, s. 325-362.

Katalog zabytków sztuki w Polsce, t. III (Województwo kieleckie), red. J.Z. Łoziński, B. Wolff, z. 3 (Powiat jędrzejowski), oprac. T. Przypkowski, Warszawa 1957.

Kosik E., Chrostowice z Małogoszcza, „Nasza Przeszłość” 1973, R. XL, s. 175-182.

Kosik E., Parafia małogoska, [w:] W kasztelańskim Małogoszczu. Monografia historyczno-gospodarcza Małogoszcza i okolicy, red. E. Kosik, Kielce 1994, s. 59-66.

Kosik E., Paulewicz M., Budowniczy Małogoszcza Jakub Bieda Chrostkowicz, [w:] W kasztelańskim Małogoszczu. Monografia historyczno-gospodarcza Małogoszcza i okolicy, red. E. Kosik, Kielce 1994, s. 67-70.

Kumor B., Dzieje diecezji krakowskiej do roku 1795, t. I, Kraków 1998. 
Kumor B., Organizacja terytorialna diecezji kieleckiej, „Nasza Przeszłość” 1963, t. XVII, s. 187-232.

Łętowski L., Katalog biskupów, prałatów i kanoników krakowskich, t. II (Biskupi krakowscy), Kraków 1852.

Mencel T., Wieś pańszczyźniana $w$ Królestwie Polskim w połowie XIX wieku, Lublin 1988.

Nitecki P., Biskupi Kościoła w Polsce w latach 965-1999, Warszawa 2000.

Rawita-Witanowski M., Dawny powiat chęciński, oprac. D. Kalina, Kielce 2001.

Stankiewicz Z., Tabele prestacyjne jako źródło wiadomości o przemianach wsi Królestwa Polskiego w połowie XIX wieku, „Przegląd Historyczny” 1962, t. LIII, z. 2, s. 311-331.

Stuczeń S. ks., Parafia małogoska i jej ostatni proboszcz ś.p. ks. prałat ks. Nestor Bieroński, „Przegląd Katolicki” 1899, R. XXXVII, nr 19, s. 296-297; nr 21, s. 328-330; nr 22, s. 345-346.

Wiśniewski J., Historyczny opis kościołów, miast, zabytków i pamiątek $w$ Jędrzejowskiem, Marjówka 1930, reprint: Kielce 2000.

Wojciechowski D. ks., Parafia w Kurzelowie, Kielce 1997.

Wróbel T., Zarys historii diecezji kieleckiej, „Kielecki Przegląd Diecezjalny” 1982, R. LVIII, nr 5, s. 204-243.

Zapałowa K., Rodzina Stefana Żeromskiego w Świętokrzyskiem, Kielce 2003. 